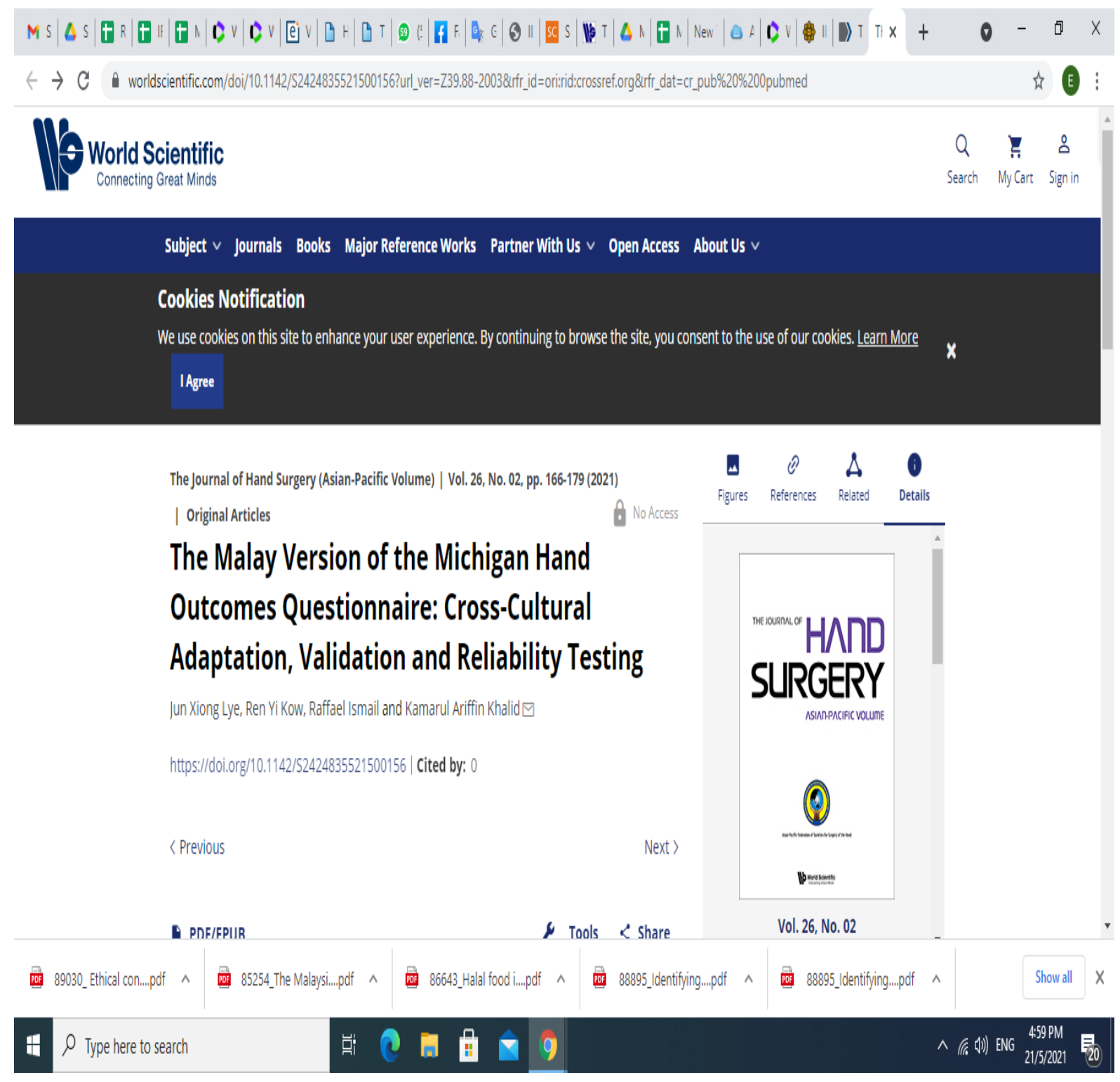




\title{
The Malay Version of the Michigan Hand Outcomes Questionnaire: Cross-Cultural Adaptation, Validation and Reliability Testing
}

\author{
Jun Xiong Lye, Ren Yi Kow, Raffael Ismail, Kamarul Ariffin Khalid \\ Department of Orthopaedics, Traumatology \& Rehabilitation, \\ International Islamic University Malaysia, Kuantan, Malaysia
}

\begin{abstract}
Background: The Michigan Hand Outcomes Questionnaire (MHQ), a self-reported questionnaire for patients with hand disorders, has been widely used globally. It has been cross-culturally adapted into different languages across all continents. Aims of this study were to translate the $\mathrm{MHO}$ into Malay language and to evaluate its reliability and validity compared with Disabilities of the Arm, Shoulder and Hand (DASH) questionnaire in a Malay-speaking population.

Methods: The MHO was cross-culturally adapted into a Malay version based on the guidelines. A pre-testing involving thirty patients with hand disorders was performed to assess whether it was comprehensible to the target population. One hundred patients with hand disorders were recruited in this study to answer the $\mathrm{MHO}$ and DASH questionnaires. The MHO was tested twice with an interval of two weeks in between. Statistical analysis was performed to assess the reproducibility and internal consistency via the test-retest method and Cronbach's alpha calculation, respectively. The association between MHO and DASH questionnaire was assessed with Spearman's correlation calculation.

Results: In the pre-testing, twenty-six patients (86.7\%) understood all the questions in the Malay version of MHO. The test-retest analysis showed a good reliability across the duration of two weeks with the intraclass correlation coefficient of all subscales ranging from 0.925 to 0.984 . Cronbach's alpha values of the Malay version MHO ranged from 0.82 to 0.97 , indicating a good internal consistency. Spearman's correlation factor of the MHQ in comparison with DASH showed a fair to moderately strong correlation with the values ranging from 0.513 to 0.757 .

Conclusions: The Malay version of MHO was successfully translated and culturally-adapted with excellent reliability (reproducibility and internal consistency) and good construct validity.
\end{abstract}

Keywords: Michigan hand outcomes questionnaire, Malaysia, Reliability, Validity, Hand

\section{INTRODUCTION}

Patient-reported outcome measures play an integral

Received: Feb. 10, 2020; Revised: Apr. 19, 2020; Accepted: Apr. 23, 2020

Published online: Jan. 11, 2021

Correspondence to: Kamarul Ariffin Khalid

Department of Orthopaedics, Traumatology \& Rehabilitation, International

Islamic University Malaysia, Kuantan 25200, Malaysia

Tel: +60-9-5704652, Fax: +60-9-5144451

E-mail: k.ariffin@iium.edu.my part of clinical research in monitoring and management of patients. ${ }^{1)}$ Since the introduction of Patient-Reported Outcomes Measurement Information System (PROMIS) by the National Institute of Health (NIH) in United States, there is a shift towards a more patient-centred health care system. ${ }^{1)}$ By implementing a patient-reported outcome measure, clinicians have a better ability in tracking the changes of clinical symptoms over time, improving the quality of care, and thence individualising the treatment plan for each patient. ${ }^{2)}$

Realising the importance of patient-reported outcome 
measures in patients with upper extremity disorders, Chung et al. have introduced the Michigan Hand Outcomes Questionnaire (MHQ) in 1998 to objectively measure the health status of patients with acute and chronic hand disorders. ${ }^{3)}$ Since then, it has been widely used globally, translated and validated in different languages, including Dutch, ${ }^{4)}$ German, ${ }^{5)}$ Japanese, ${ }^{6)}$ Korean, ${ }^{7)}$ Polish, ${ }^{8)}$ Brazilian Portuguese, ${ }^{9)}$ Turkish ${ }^{10)}$ and others. MHQ comprises a total of 37 core questions over six domains including overall hand function, activities of daily living, work performance, pain, aesthetics and patient satisfaction. $^{3)}$ Each domain is scored by totalling up the responses (ranging from 1 to 5) from each question within that domain, and normalizing the scores into a scale of 0 to $100 .^{3)}$ A higher score indicates a better hand function except for the pain domain where the opposite holds true. ${ }^{3)}$ MHQ is the only questionnaire in use that distinguishes the difference between both hands, more sensitive to functional changes in the affected hand and provides a more detailed assessment including pain and aesthetical concerns compared to Disabilities of the Arm, Shoulder and Hand Questionnaire (DASH) and Duruoz Hand In$\operatorname{dex}(\mathrm{DHI}){ }^{11,12)}$

Malay language is a lingua franca used in South East Asia (SEA) countries such as Malaysia, Indonesia, Brunei, Singapore and part of Thailand. On that account, there is a great value in developing a Malay language version of MHQ to improve the modulation of patients with hand disorders in SEA countries. In the present study, we establish a Malay version of the MHQ with a cross-cultural adaptation and translation method and evaluate its reliability and validity among patients with hand disorders.

\section{METHODS}

This cross-sectional study consisted of two phases: translation and cross-cultural adaptation of the MHQ into the Malay language, and validity and reliability testing of the newly constructed Malay version of the MHQ (Fig. 1). The study was approved by the Kulliyah Research Committee (KRC) of International Islamic University Malaysia (IIUM), IIUM Research Ethics Committee (IREC), and Medical Research and Ethics Committee (MREC) of Ministry of Health, Malaysia. A full licence agreement was obtained from The Regents of the University of Michigan for academic, research and educational use of the MHQ.

\section{Translation and cross-cultural adaptation}

The translation and cross-cultural adaptation of the Malay version of MHQ was performed based on guidelines outlined by Beaton. ${ }^{13)}$ The English version of the MHQ was translated into Malay language by two translators, consisting of an orthopaedic resident and a "naive" translator without any medical background and was unaware of the concepts being examined. Both translators considered Malay language as their mother tongue and were fluent in English. The translated Malay version of MHQs were termed T1 and T2 respectively (Fig. 1). Both $\mathrm{T} 1$ and $\mathrm{T} 2$ were then synthesized into a single Malay MHQ (T-12) through a conference attended by investigators (all authors) and the two translators. The MHQ (T-12) in Malay language was then translated back into English by another two independent translators into BT1 and BT2 respectively. The independent translators had an academic background of teaching English language at the National Energy University (UNITEN), Malaysia and Brock University, Canada respectively, and both were not aware of the original MHQ. A tentative Malay version of MHQ was constructed in a conference con-

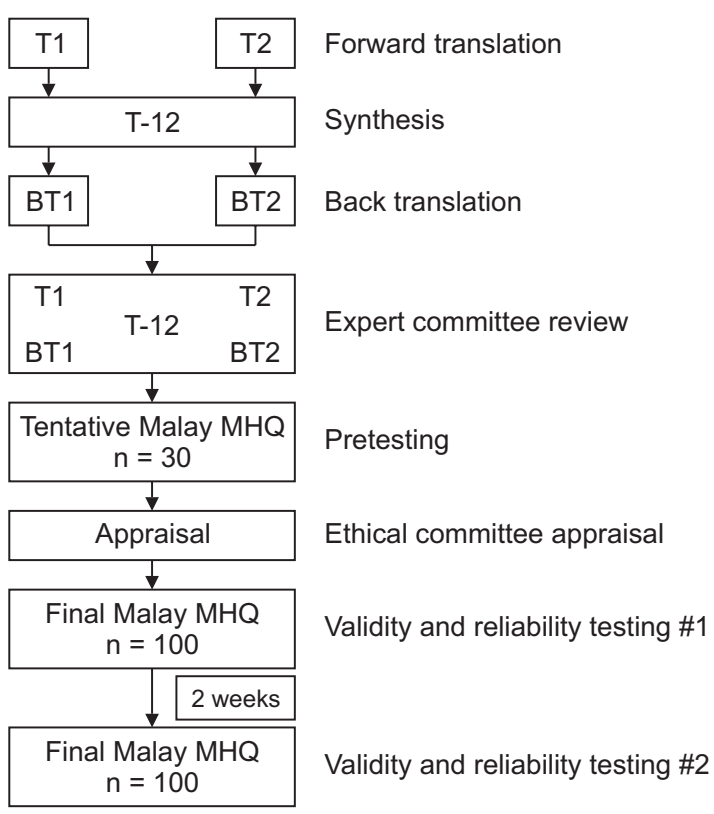

Fig. 1. Flowchart illustrates the study methodology in adaptation and translation of the Malay version of Michigan Hand Outcomes Questionnaire (MHQ). T1, T2, BT1 and BT2 are made by four independent translators: T1 - first translation from English into Malay language by an orthopaedic resident; T2 - second translation from English into Malay language by a non-medical personnel; T-12 - synthesis of two forward translations into one Malay version; BT1 - first backward translation from Malay into English by an English teacher; BT2 - second backward translation from Malay into English by another English teacher. 
taining all the investigators and four translators (T1, T2, BT1 and BT2) and any discrepancy was resolved via discussion. It was subsequently subjected to a pre-testing by thirty patients with hand disorders. The final version of Malay MHQ was then drafted, and all the results were subjected to appraisal by ethical committees (KRC, IREC and MREC) to ensure the veracity of the study.

\section{Patient selection}

Patients with various hand disorders were recruited from the Hand Clinic at International Islamic University Malaysia Medical Centre (IIUMMC) from July 2018 to May 2019. A total of 100 consecutive patients were enrolled into this study. The inclusion criteria were age 18 years and above, able to complete the questionnaire and having Malay as their first language. Patients who were illiterate, having neurological disorder or those who had undergone change of treatment plan during the study period were excluded from the study.

Potential patients were identified by one of the investigators in the clinic and they were invited to participate in the study. Once a written consent was obtained, patient's demographic and clinical data were retrieved. All patients were given Malay version of MHQ and DASH, with the MHQ to be completed first. All of them were requested to complete a similar set of questionnaires two weeks later.

\section{Statistical analysis}

All data obtained was analyzed with Statistical Package for Social Science (SPSS) Statistics software version 20 following methods performed in the reliability and validity testing by other MHQ studies. ${ }^{4-10)}$ The demographic and clinical data were analyzed descriptively.

Reliability, a measure of overall consistency, was dichotomized into internal consistency and reproducibility. Cronbach's alpha was utilized to test the internal consistency, in which the consistency of respondents' answers across all MHQ items was evaluated. ${ }^{14)}$ The Cronbach's alpha was described in a coefficient (ranging from 0 to 1), with the higher number (more than 0.7 ) indicating a relevant internal consistency. ${ }^{7}$ Reproducibility (testretest), an assessment of similar answer grading across two separate occasions, was measured with the intraclass correlation coefficient (ICC). A higher ICC value reflected a better reproducibility, with an ICC of $\geq 0.7$ being considered acceptable but a value of $\geq 0.8$ was much preferred. $^{15)}$

Validity, a measure of how well the scales in a questionnaire behave as expected, was evaluated by Spear- man correlation coefficients between the Malay version of MHQ and a questionnaire of similar concept. ${ }^{7)}$ By hypothesizing the Malay MHQ score would have an association with the validated Malay version of Disability of Arm, Shoulder and Hand (DASH) questionnaire, patients were tasked to answer the Malay version of both MHQ and DASH questionnaire during their first clinic visits. ${ }^{16)}$ The DASH questionnaire was opted for comparison to construct validity due to its reliability and validity in assessment of patients with hand disorders and to the fact that hitherto it was the only questionnaire with a validated Malay version. ${ }^{16,17)}$

Table 1. Demographic Data of Patients Included in the Validity and Reliability Testing

\begin{tabular}{|c|c|}
\hline Variables & Frequency (\%) \\
\hline \multicolumn{2}{|l|}{ Gender } \\
\hline Male & $47(47.0)$ \\
\hline Female & $53(53.0)$ \\
\hline \multicolumn{2}{|l|}{ Dominant hand } \\
\hline Right & $70(70.0)$ \\
\hline Left & $11(11.0)$ \\
\hline Both & $19(19.0)$ \\
\hline \multicolumn{2}{|l|}{ Injured hand } \\
\hline Right & $40(40.0)$ \\
\hline Left & $36(36.0)$ \\
\hline Ambidextrous & $24(24.0)$ \\
\hline \multicolumn{2}{|l|}{ Change of job after injury } \\
\hline Yes & $13(13.0)$ \\
\hline No & $87(87.0)$ \\
\hline \multicolumn{2}{|l|}{ Ethnic } \\
\hline Malay & $66(66.0)$ \\
\hline Chinese & $22(22.0)$ \\
\hline Indian & $11(11.0)$ \\
\hline Others & $1(1.0)$ \\
\hline \multicolumn{2}{|l|}{ Level of education } \\
\hline Up to secondary school & $51(51.0)$ \\
\hline Diploma & $18(18.0)$ \\
\hline Degree & $30(30.0)$ \\
\hline Postgraduate & $1(1.0)$ \\
\hline \multicolumn{2}{|l|}{ Income } \\
\hline$<$ RM 3000 & $54(54.0)$ \\
\hline RM 3000-RM 6000 & $29(29.0)$ \\
\hline RM 6001-RM 10000 & $13(13.0)$ \\
\hline$>$ RM 10000 & $4(4.0)$ \\
\hline \multicolumn{2}{|l|}{ PERKESO compensation } \\
\hline Yes & $39(39.0)$ \\
\hline No & $61(61.0)$ \\
\hline
\end{tabular}

$n=100$, mean age $=49.43 \pm 15.35$. $R M$ : ringgit malaysia. 


\section{RESULTS}

\section{Demographic data of patients}

One hundred consecutive patients with hand disorders were recruited for the validity and reliability testing of the Malay version of MHQ. All patients completed both the questionnaires. The demographic data of the enrolled patients were summarized in Table 1 .

\section{Translation and cross-cultural adaptation}

Translators reported no cultural or linguistic problem in both forward and back translations of the MHQ. None of the activities was renamed or altered because of transcultural adaptation. However, there were a few questions in the demographic section which were adapted to the Malaysian context. For the question about ethnic background, instead of "White", "Black" and "Asian" which were applicable in the western context, Malaysian ethnicities of "Malay", "Chinese", "Indian" and "Others" were applied. Besides that, regarding the highest level of education that the patient had received, "less than high school graduate" was adapted to "up to secondary school". In terms of the family income, the scale range has been adapted based on the report by Department of Statistics Malaysia in which the income limits for bottom 40\% (B40), middle 40\% (M40) and top 20\% (T20) were RM3,000, RM6,275 and RM13,148 respectively. ${ }^{18)}$ We classified the family income into four categories: 1) less than RM3000; 2) RM3000 to RM6000; 3) RM6000 to RM10000; and 4) more than RM10000, for ease of patient recall and reporting. Last but not least, for the "Worker's Compensation", it had been renamed to "PERKESO", the official organization handling workers' compensation in Malaysia.

Table 2. Test-Retest Reproducibility and Internal Consistency of the Malay Version of $\mathrm{MHO}$

\begin{tabular}{llcc}
\hline \multirow{2}{*}{ MHO } & $\begin{array}{c}\text { Intraclass } \\
\text { correlation }\end{array}$ & $\begin{array}{c}\text { Cronbach's } \\
\text { alpha }\end{array}$ \\
\hline Hand function & Right hand & 0.957 & 0.95 \\
Activities of daily living & Left hand & 0.981 & 0.96 \\
& Right hand & 0.984 & 0.97 \\
& Left hand & 0.982 & 0.95 \\
Work performance & Both hands & 0.970 & 0.95 \\
Pain & & 0.928 & 0.95 \\
Aesthetic & Right hand & 0.961 & 0.82 \\
\multirow{2}{*}{ Satisfaction with hand } & Left hand & 0.982 & 0.95 \\
function & Right hand & 0.958 & 0.96 \\
& Left hand & 0.925 & 0.94 \\
\hline
\end{tabular}

During the pre-testing stage, the tentative Malay version of MHQ was distributed to 30 random patients who were receiving treatment at IIUMMC Hand Clinic. Twenty-six patients (86.7\%) understood all the questions in the MHQ in Malay language. The translation of MHQ into Malay language was accepted as the final version as it was comprehensible to more than $80 \%$ of the participants. The final version of the Malay MHQ is attached (Appendix 1). There was no deviation in the study protocol. All participants who had agreed to comply with the protocol completed the whole evaluation, and the investigator checked whether each question had been answered before the patients left.

\section{Reliability analysis}

All patients completed the questionnaire at the clinic and a second identical questionnaire was given 2 weeks later to assess the test-retest reproducibility of the Malay version of MHQ. The results of intraclass correlation for the test-retest reliability were highlighted in Table 2 . The intraclass correlation coefficient (ICC) analysis was used to determine the consistency of the construct between two different time intervals. The ICCs of all subscales were more than 0.9 , signifying an excellent reliability between two different time intervals. ${ }^{19)}$ The internal consistency of the MHQ was acceptable as evidenced by Cronbach's alpha of more than 0.7 , indicating that all the subscales of MHQ measured the same concept. ${ }^{20)}$

\section{Validity analysis}

Construct validity was assessed by comparing correlations between the results of MHQ and DASH. The results and strength of correlations were summarized in Table 3. Overall, the correlation between MHQ and DASH was moderately strong, as evidenced by a Spearman's correlation coefficient of $-0.726 .{ }^{21)}$ Individually, two subscales (hand function and activity of daily liv-

Table 3. Spearman's Correlation Factors of the MHO Compared with DASH

\begin{tabular}{lcll}
\hline MHO subscales & $\begin{array}{c}\text { Correlation } \\
\text { coefficient }\end{array}$ & $\begin{array}{c}\text { Strength of } \\
\text { correlation }^{211}\end{array}$ & $p$-value \\
\hline Hand function & -0.662 & Moderately strong & $<0.001$ \\
Activity of daily living & -0.757 & Moderately strong & $<0.001$ \\
Work performance & -0.559 & Fair to moderately strong & $<0.001$ \\
Pain & 0.574 & Fair to moderately strong & $<0.001$ \\
Aesthetic & -0.513 & Fair to moderately strong & $<0.001$ \\
Satisfaction & -0.574 & Fair to moderately strong & $<0.001$ \\
Total & -0.726 & Moderately strong & $<0.001$ \\
\hline
\end{tabular}


ing) showed a moderately strong correlation and four subscales (work performance, pain, aesthetic and satisfaction) showed a fair to moderately strong correlation between MHQ and DASH.

\section{DISCUSSION}

As a developing country, Malaysia is going through rapid industrialization. Consequently, the number of industrial-related accidents is also on the rise. Among them, $24.9 \%$ of the industrial accidents are work-related hand injuries and up to $30 \%$ of the occupational accidents treated at the emergency department involve the upper limbs. ${ }^{22)}$ This places a huge economic burden on the country via loss of human workforce. Since the introduction of MHQ in 1998, healthcare workers dealing with patients suffering from upper limb disorders have been utilizing it to monitor disease progression and to individualise the treatment plan for each patient. The questionnaire can be used as an instrument to convey subjective feelings of patients (such as pain, emotions, etc) to clinicians with an objective numerical and reproducible scale, which subsequently enables monitoring of disease progression. Since the MHQ is a self-administered questionnaire, patients are expected to have a certain level of English proficiency to comprehend and to complete the questionnaire. Furthermore, some aspects in the MHQ, like hand functions and activities of daily living, require transcultural adaptation into the local setting.

In this study, a Malay version of MHQ was constructed following a systematic and standardized approach for cross-cultural adaptation of a self-assessment questionnaire outlined by Beaton et al. ${ }^{13)}$ Similar to studies conducted in Japan and Korea, there were some minor discrepancies due to cultural differences between North America and Asian countries. ${ }^{6,7)}$ We have successfully adapted and cross-culturally translated the MHQ and showed that the Malay version of MHQ is an instrument that has test-retest reproducibility, internal consistency as well as validity. In this study, we excluded patients who had undergone change of treatment plan during the study period to prevent intrapersonal variables. Any change of treatment may deviate the patient-reported outcomes, either for the better or worse.

The MHQ in Malay language has produced consistent and reproducible results over a duration of two weeks. A test-retest interval of two weeks was used to avoid patients from recalling the content of the questionnaire in the first encounter, echoing the opinion of authors from Brazil. ${ }^{9)}$ The level of intraclass correlation coefficient (ICC) of Malay MHQ was excellent, as all the ICC values were more than 0.9. This result is similar to the original study by Chung et al., in which all the subscales ICC demonstrated an excellent correlation except for aesthetic of the left hand that showed good correlation. ${ }^{3)}$ Similarly, the internal consistencies of the subscales were acceptable (Cronbach's alpha $>0.7$ ), indicating that each subscale obtained a homogenous and conceptual testing in the Malay MHQ. In contrast to the studies performed in Japan, Korea and Turkey, the value of Cronbach's alpha was lowest in the subscale of pain in our study. ${ }^{6,7,10)}$

The construct validity of the Malay version of MHQ was assessed by comparison with DASH, the only available questionnaire in Malay language for hand disorders. ${ }^{16)}$ Although it is useful in assessing the function of patients with hand disorders, DASH does not provide information on patient's aesthetic view, hence lacking a critical dimension in the complete assessment of patients. Similar to other studies, the correlation between MHQ and DASH was moderately strong in the subscales of hand function (Spearman's correlation coefficient -0.662 ) and activity of daily living (Spearman's correlation coefficient -0.757 ) with a good overall correlation between the two questionnaires (Spearman's correlation coefficient -0.726$).{ }^{6,7)}$ Individually, the aesthetic subscale showed the lowest correlation coefficient, which was expected as the MHQ is the only questionnaire with aesthetic assessment between the two.

This study has several limitations. In this study, the validity of the Malay version of MHQ is assessed by comparison with the conventional DASH, the only Malay version available at the time of study. This is aimed to cater for our patients of mixed educational background, as not all patients are well-versed in English. There will be a selection bias if we exclude all patients who are not proficient in English. Nevertheless, we propose that future studies to focus on detailed evaluation on the validity of Malay version of MHQ with other measurement tools such as the now-available Malay version of work-related DASH and sports art-related DASH, as well as comparison with visual analogue scale (VAS) which can transcend language barrier.

In conclusion, the Malay version of the MHQ was successfully translated and adapted, with excellent reliability (reproducibility and internal consistency) and good construct validity. 
Jun Xiong Lye, et al. Malay Version Michigan Hand Outcomes Questionnaire

\section{ACKNOWLEDGMENTS}

This work was supported by the International Islamic University Malaysia grant number RIGS16-331-0495.

\section{REFERENCES}

1. Evans JP, Smith A, Gibbons C, Alonso J, Valderas JM. The national institutes of health patient-reported outcomes measurement information system (PROMIS): a view from the UK. Patient Relat Outcome Meas. 2018;9:345-52.

2. Philpot LM, Barnes SA, Brown RM, Austin JA, James CS, Stanford RH, Ebbert JO. Barriers and benefits to the use of patient-reported outcome measures in routine clinical care: a qualitative study. Am J Med Qual. 2018;33(4):359-64.

3. Chung KC, Pillsbury MS, Walters MR, Hayward RA. Reliability and validity testing of the Michigan hand outcomes questionnaire. J Hand Surg Am. 1998;23(4):575-87.

4. Van der Giesen FJ, Nelissen RG, Arendzen JH, de Jong Z, Wolterbeek R, Vliet Vlieland TP. Responsiveness of the Michigan hand outcomes questionnaire - dutch language version in patients with rheumatoid arthritis. Arch Phys Med Rehabil. 2008;89(6)1121-6.

5. Knobloch K, Kuehn M, Papst S, Kraemer R, Vogt PM. German standardized translation of the Michigan hand outcomes questionnaire for patient-related outcome measurement in Dupuytren disease. Plast Reconstr Surg. 2011; 128(1):39e-40e.

6. Oda T, Abe Y, Katsumi Y, Ohi H, Nakamura T, Inagaki $\mathrm{K}$. Reliability and validity of the Japanese version of the Michigan hand outcomes questionnaire: a comparison with the DASH and SF-36 questionnaires. J Hand Surg Asia Pac. 2016;21(1):72-7.

7. Roh YH, Yang BK, Noh JH, Baek GH, Song CH, Gong HS. Cross-cultural adaptation and validation of the Korean version of the Michigan hand questionnaire. J Hand Surg Am. 2011;36(9):1497-503.

8. Koziej M, Trybus M, Mydlowska A, Salapa K, Gniadek M, Banach M, Brudnicki J. The Polish version of the Michigan hand outcomes questionnaire: cross-cultural adaptation, reliability, construct validity, and measurement error. J Hand Surg Eur Vol. 2018;43(2):199-208.

9. Meireles SM, Natour J, Batista DA, Lopes M, Skare TL. Cross-cultural adaptation and validation of the Michigan hand outcomes questionnaire for Brazil. Sao Paulo Med J.
2014;123(6):339-47.

10. Öksüz Ç, Akel BS, Oskay D, Leblebicioglu G, Hayran KM. Cross-cultural adaptation, validation, and reliability process of the Michigan hand outcomes questionnaire in a Turkish population. J Hand Surg Am. 2011;36(3):486-92.

11. Waljee JF, Kim HM, Burns PB, Chung KC. Development of a brief, 12-item version of the Michigan hand questionnaire. Plast Reconstr Surg 2011;128(1):208-20.

12. Dogu B, Usen A, Kuran B, Yilmaz F, Sirzai H. Comparison of responsiveness of Michigan hand outcomes questionnaire, disabilities of the arm, shoulder and hand questionnaire, and duruoz hand index in patients with traumatic hand injury. J Back Musculoskelet Rehabil 2019;32(1):1117.

13. Beaton DE, Bombardier C, Guillemin F, Ferraz MB. Guidelines for the process of cross-cultural adaptation of self-report measures. Spine 2000;25:3186-91.

14. Cronbach LJ. A case study of the split-half reliability coefficient. J Educ Psychol 1946;37:473-80.

15. Marks M, Audigé L, Herren DB, Schindele S, Nelissen RG, Vliet Vlieland TP. Measurement properties of the German Michigan Hand Outcomes Questionnaire in patients with trapeziometacarpal osteoarthritis. Arthritis Care Res 2014;66(2):245-52.

16. Ameer A, Lekhraj R, Manohar A, Hejar AR, Jama'Yah Z. Validation of a Malay version of Disability of Arm, Shoulder and Hand questionnaire (MVDASH). In: 3rd Asian pacific conference on public health, Grand Dorsett, Subang, Malaysia, 14-15 November 2011.

17. Szabo RM. Outcomes assessment in hand surgery: when are they meaningful? J Hand Surg 2001;26A:993-1002.

18. Department of Statistics Malaysia. Report of Household Income and Basic Amenities Survey 2016. DOSM. Press Release, 9 Oct 2017. https://www.dosm.gov.my/v1/index. php?r=column/pdfPrev\&id=RUZ5REwveU1ra1hGL21JW VlPRmU2Zz09. Accessed 9 Dec 2017.

19. Koo TK, Li MY. A Guide of Selecting and Reporting Intraclass Correlation Coefficients for Reliability Research. J Chiropr Med. 2016;15(2):155-63.

20. Tavakol M. Dennick R. Making sense of Cronbach's alpha. International Journal of Medical Education. 2011;2:53-5.

21. Chan YH. Biostatistics 104: correlational analysis. Singap Med J. 2003;44(12):614-9.

22. Ganesh CS, Krishnan R. A review of occupational injury research in Malaysia. Med J Malaysia. 2016;71(1):100-4. 
Appendix 1

\section{Michigan Hand Outcomes Questionnaire ${ }^{1}$ - Malay Version}

(Soal Selidik Hasil Tangan Michigan)

Arahan: Tinjauan ini bertujuan mendapatkan pandangan anda tentang tangan dan kesihatan anda. Maklumat ini akan membantu memantau kesihatan anda dan sejauh mana anda mampu melakukan aktiviti biasa. Jawab setiap soalan dengan menandakan jawapan seperti yang ditunjukkan. Jika anda tidak pasti cara untuk menjawab soalan, sila berikan jawapan terbaik yang boleh diberikan.

I. Soalan berikut merujuk fungsi tangan/pergelangan tangan anda pada minggu lepas. (Sila bulatkan 1 jawapan untuk setiap soalan).

A. Soalan berikut merujuk tangan/pergelangan tangan kanan anda.

\begin{tabular}{|l|c|c|c|c|c|}
\hline & Sangat Baik & Baik & Sederhana & Teruk & Sangat Teruk \\
\hline $\begin{array}{l}\text { 1. Secara keseluruhan, sebaik } \\
\text { manakah tangan kanan anda } \\
\text { berfungsi? }\end{array}$ & 1 & 2 & 3 & 4 & 5 \\
\hline $\begin{array}{l}\text { 2. Sebaik manakah jari kanan } \\
\text { anda boleh digerakkan? }\end{array}$ & 1 & 2 & 3 & 4 & 5 \\
\hline $\begin{array}{l}\text { 3. Sebaik manakah pergelangan } \\
\text { tangan kanan anda boleh } \\
\text { digerakkan? }\end{array}$ & 1 & 2 & 3 & 4 & 5 \\
\hline $\begin{array}{l}\text { 4. Sekuat manakah tangan } \\
\text { kanan anda? }\end{array}$ & 1 & 2 & 3 & 4 & 5 \\
\hline $\begin{array}{l}\text { 5. Bagaimanakah deria (rasa) } \\
\text { pada tangan kanan anda? }\end{array}$ & 1 & 2 & 3 & 4 & 5 \\
\hline
\end{tabular}

B. Soalan berikut merujuk tangan/pergelangan tangan kiri anda.

\begin{tabular}{|l|c|c|c|c|c|}
\hline & Sangat Baik & Baik & Sederhana & Teruk & Sangat Teruk \\
\hline $\begin{array}{l}\text { 1. Secara keseluruhan, sebaik } \\
\text { manakah tangan kiri anda } \\
\text { berfungsi? }\end{array}$ & 1 & 2 & 3 & 4 & 5 \\
\hline $\begin{array}{l}\text { 2. Sebaik manakah jari kiri anda } \\
\text { boleh digerakkan? }\end{array}$ & 1 & 2 & 3 & 4 & 5 \\
\hline $\begin{array}{l}\text { 3. Sebaik manakah pergelangan } \\
\text { tangan kiri anda boleh } \\
\text { digerakkan? }\end{array}$ & 1 & 2 & 3 & 4 & 5 \\
\hline $\begin{array}{l}\text { 4. Sekuat manakah tangan kiri } \\
\text { anda? }\end{array}$ & 1 & 2 & 3 & 4 & 5 \\
\hline $\begin{array}{l}\text { 5. Bagaimanakah deria (rasa) } \\
\text { pada tangan kiri anda? }\end{array}$ & 1 & 2 & 3 & 4 & 5 \\
\hline
\end{tabular}


II. Soalan berikut merujuk keupayaan tangan anda untuk melakukan tugas tertentu pada minggu lepas. (Sila bulatkan 1 jawapan untuk setiap soalan).

A. Sejauh manakah anda mengalami kesukaran untuk melakukan aktiviti yang berikut menggunakan tangan kanan anda?

\begin{tabular}{|l|c|c|c|c|c|}
\hline & Tidak Sukar & $\begin{array}{c}\text { Sedikit } \\
\text { Sukar }\end{array}$ & $\begin{array}{c}\text { Agak } \\
\text { Sukar }\end{array}$ & $\begin{array}{c}\text { Sederhana } \\
\text { Sukar }\end{array}$ & $\begin{array}{c}\text { Sangat } \\
\text { Sukar }\end{array}$ \\
\hline 1. Memusing tombol pintu & 1 & 2 & 3 & 4 & 5 \\
\hline 2. Mengutip duit syiling & 1 & 2 & 3 & 4 & 5 \\
\hline 3. Memegang segelas air & 1 & 2 & 3 & 4 & 5 \\
\hline 4. Memutar kunci & 1 & 2 & 3 & 4 & 5 \\
\hline 5. Memegang kuali & 1 & 2 & 3 & 4 & 5 \\
\hline
\end{tabular}

B. Sejauh manakah anda mengalami kesukaran untuk melakukan aktiviti yang berikut menggunakan tangan kiri anda?

\begin{tabular}{|l|c|c|c|c|c|}
\hline & Tidak Sukar & $\begin{array}{c}\text { Sedikit } \\
\text { Sukar }\end{array}$ & $\begin{array}{c}\text { Agak } \\
\text { Sukar }\end{array}$ & $\begin{array}{c}\text { Sederhana } \\
\text { Sukar }\end{array}$ & $\begin{array}{c}\text { Sangat } \\
\text { Sukar }\end{array}$ \\
\hline 1. Memusing tombol pintu & 1 & 2 & 3 & 4 & 5 \\
\hline 2. Mengutip duit syiling & 1 & 2 & 3 & 4 & 5 \\
\hline 3. Memegang segelas air & 1 & 2 & 3 & 4 & 5 \\
\hline 4. Memutar kunci & 1 & 2 & 3 & 4 & 5 \\
\hline 5. Memegang kuali & 1 & 2 & 3 & 4 & 5 \\
\hline
\end{tabular}

C. Sejauh manakah anda mengalami kesukaran untuk melakukan aktiviti yang berikut menggunakan kedua-dua tangan anda?

\begin{tabular}{|l|c|c|c|c|c|}
\hline & Tidak Sukar & $\begin{array}{c}\text { Sedikit } \\
\text { Sukar }\end{array}$ & $\begin{array}{c}\text { Agak } \\
\text { Sukar }\end{array}$ & $\begin{array}{c}\text { Sederhana } \\
\text { Sukar }\end{array}$ & $\begin{array}{c}\text { Sangat } \\
\text { Sukar }\end{array}$ \\
\hline 1. Membuka balang & 1 & 2 & 3 & 4 & 5 \\
\hline 2. Membutangkan kemeja/blaus & 1 & 2 & 3 & 4 & 5 \\
\hline $\begin{array}{l}\text { 3. Makan menggunakan } \\
\text { pisau/garpu }\end{array}$ & 1 & 2 & 3 & 4 & 5 \\
\hline 4. Membawa beg barang runcit & 1 & 2 & 3 & 4 & 5 \\
\hline 5. Mencuci pinggan mangkuk & 1 & 2 & 3 & 4 & 5 \\
\hline 6. Mencuci rambut & 1 & 2 & 3 & 4 & 5 \\
\hline 7. Mengikat tali kasut/simpulan & 1 & 2 & 3 & 4 & 5 \\
\hline
\end{tabular}


III. Soalan berikut merujuk cara anda melakukan kerja biasa (termasuk kerja rumah dan kerja sekolah) pada 4 minggu lepas. (Sila bulatkan 1 jawapan untuk setiap soalan).

\begin{tabular}{|c|c|c|c|c|c|}
\hline & Selalu & Kerap & $\begin{array}{c}\text { Kadang } \\
\text { kala }\end{array}$ & $\begin{array}{l}\text { Jarang } \\
\text { sekali }\end{array}$ & $\begin{array}{l}\text { Tidak } \\
\text { pernah }\end{array}$ \\
\hline $\begin{array}{l}\text { 1. Berapa kerapkah anda tidak } \\
\text { dapat melakukan kerja kerana } \\
\text { masalah pada } \\
\text { tangan/pergelangan tangan } \\
\text { anda? }\end{array}$ & 1 & 2 & 3 & 4 & 5 \\
\hline $\begin{array}{l}\text { 2. Berapa kerapkah anda perlu } \\
\text { memendekkan hari kerja kerana } \\
\text { masalah pada } \\
\text { tangan/pergelangan tangan } \\
\text { anda? }\end{array}$ & 1 & 2 & 3 & 4 & 5 \\
\hline $\begin{array}{l}\text { 3. Berapa kerapkah anda perlu } \\
\text { berehat semasa bekerja kerana } \\
\text { masalah pada } \\
\text { tangan/pergelangan tangan } \\
\text { anda? }\end{array}$ & 1 & 2 & 3 & 4 & 5 \\
\hline $\begin{array}{l}\text { 4. Berapa kerapkah kerja anda } \\
\text { kurang sempurna kerana } \\
\text { masalah pada } \\
\text { tangan/pergelangan tangan } \\
\text { anda? }\end{array}$ & 1 & 2 & 3 & 4 & 5 \\
\hline $\begin{array}{l}\text { 5. Berapa kerapkah anda } \\
\text { mengambil masa yang lebih } \\
\text { lama untuk melakukan tugasan } \\
\text { dalam kerja kerana masalah } \\
\text { pada tangan/pergelangan tangan } \\
\text { anda? }\end{array}$ & 1 & 2 & 3 & 4 & 5 \\
\hline
\end{tabular}


IV. Soalan berikut merujuk tahap kesakitan yang anda alami pada tangan/pergelangan tangan pada minggu lepas. (Sila bulatkan 1 jawapan untuk setiap soalan).

1. Berapa kerapkah anda mengalami kesakitan pada tangan/pergelangan tangan anda?

1. Selalu

2. Kerap

3. Kadang kala

4. Jarang sekali

5. Tidak pernah

Jika anda menjawab tidak pernah pada soalan IV-I di atas, sila langkau soalan-soalan berikut dan pergi ke soalan $\mathrm{V}-\mathrm{A}-1$ pada mukasurat seterusnya.

2. Sila terangkan kesakitan yang anda alami pada tangan/pergelangan tangan anda.

1. Sangat ringan

2. Ringan

3. Sederhana

4. Teruk

5. Sangat teruk

\begin{tabular}{|l|c|c|c|c|c|}
\hline & Selalu & Kerap & $\begin{array}{c}\text { Kadang } \\
\text { kala }\end{array}$ & $\begin{array}{c}\text { Jarang } \\
\text { sekali }\end{array}$ & $\begin{array}{c}\text { Tidak } \\
\text { pernah }\end{array}$ \\
\hline $\begin{array}{l}\text { 3. Berapa kerapkah kesakitan pada } \\
\text { tangan/pergelangan tangan } \\
\text { mengganggu tidur anda? }\end{array}$ & 1 & 2 & 3 & 4 & 5 \\
\hline $\begin{array}{l}\text { 4. Berapa kerapkah kesakitan pada } \\
\text { tangan/pergelangan tangan } \\
\text { mengganggu aktiviti harian anda } \\
\text { (seperti makan atau mandi)? }\end{array}$ & 1 & 2 & 3 & 4 & 5 \\
\hline $\begin{array}{l}\text { 5. Berapa kerapkah kesakitan pada } \\
\text { tangan/pergelangan tangan } \\
\text { menyebabkan anda berasa tidak } \\
\text { gembira? }\end{array}$ & 1 & 2 & 3 & 4 & 5 \\
\hline
\end{tabular}


V. A. Soalan berikut merujuk keadaan (rupa) tangan kanan anda pada minggu lepas.

(Sila bulatkan 1 jawapan untuk setiap soalan).

\begin{tabular}{|l|c|c|c|c|c|}
\hline & $\begin{array}{c}\text { Sangat } \\
\text { Setuju }\end{array}$ & Setuju & Neutral & $\begin{array}{c}\text { Tidak } \\
\text { Setuju }\end{array}$ & $\begin{array}{c}\text { Sangat } \\
\text { Tidak } \\
\text { Setuju }\end{array}$ \\
\hline $\begin{array}{l}\text { 1. Saya berpuas hati dengan } \\
\text { keadaan (rupa) tangan kanan } \\
\text { saya. }\end{array}$ & 1 & 2 & 3 & 4 & 5 \\
\hline $\begin{array}{l}\text { 2. Keadaan (rupa) tangan kanan } \\
\text { saya kadang kala menyebabkan } \\
\text { saya berasa tidak selesa di tempat } \\
\text { awam. }\end{array}$ & 1 & 2 & 3 & 4 & 5 \\
\hline $\begin{array}{l}\text { 3. Keadaan (rupa) tangan kanan } \\
\text { saya membuatkan saya berasa } \\
\text { murung. }\end{array}$ & 1 & 2 & 3 & 4 & 5 \\
\hline $\begin{array}{l}\text { 4. Keadaan (rupa) tangan kanan } \\
\text { saya mengganggu aktiviti sosial } \\
\text { biasa saya. }\end{array}$ & 1 & 2 & 3 & 4 & 5 \\
\hline
\end{tabular}

B. Soalan berikut merujuk keadaan (rupa) tangan kiri anda pada minggu lepas.

(Sila bulatkan 1 jawapan untuk setiap soalan).

\begin{tabular}{|l|c|c|c|c|c|}
\hline & $\begin{array}{c}\text { Sangat } \\
\text { Setuju }\end{array}$ & Setuju & Neutral & $\begin{array}{c}\text { Tidak } \\
\text { Setuju }\end{array}$ & $\begin{array}{c}\text { Sangat } \\
\text { Tidak } \\
\text { Setuju }\end{array}$ \\
\hline $\begin{array}{l}\text { 1. Saya berpuas hati dengan } \\
\text { keadaan (rupa) tangan kiri saya. }\end{array}$ & 1 & 2 & 3 & 4 & 5 \\
\hline $\begin{array}{l}\text { 2. Keadaan (rupa) tangan kiri saya } \\
\text { kadang kala menyebabkan saya } \\
\text { berasa tidak selesa di tempat } \\
\text { awam. }\end{array}$ & 1 & 2 & 3 & 4 & 5 \\
\hline $\begin{array}{l}\text { 3. Keadaan (rupa) tangan kiri saya } \\
\text { membuatkan saya berasa murung. }\end{array}$ & 1 & 2 & 3 & 4 & 5 \\
\hline $\begin{array}{l}\text { 4. Keadaan (rupa) tangan kiri saya } \\
\text { mengganggu aktiviti sosial biasa } \\
\text { saya. }\end{array}$ & 1 & 2 & 3 & 4 & 5 \\
\hline
\end{tabular}


VI. A. Soalan berikut merujuk tahap kepuasan anda terhadap tangan/pergelangan tangan kanan anda pada minggu lepas.

(Sila bulatkan 1 jawapan untuk setiap soalan).

\begin{tabular}{|l|c|c|c|c|c|}
\hline & $\begin{array}{c}\text { Sangat } \\
\text { Berpuas } \\
\text { Hati }\end{array}$ & $\begin{array}{c}\text { Agak } \\
\text { Berpuas } \\
\text { Hati }\end{array}$ & Neutral & $\begin{array}{c}\text { Agak Tidak } \\
\text { Berpuas } \\
\text { Hati }\end{array}$ & $\begin{array}{c}\text { Sangat } \\
\text { Tidak } \\
\text { Berpuas } \\
\text { Hati }\end{array}$ \\
\hline $\begin{array}{l}\text { 1. Fungsi keseluruhan tangan } \\
\text { kanan anda }\end{array}$ & 1 & 2 & 3 & 4 & 5 \\
\hline $\begin{array}{l}\text { 2. Pergerakan jari tangan kanan } \\
\text { anda }\end{array}$ & 1 & 2 & 3 & 4 & 5 \\
\hline $\begin{array}{l}\text { 3. Pergerakan pergelangan tangan } \\
\text { kanan anda }\end{array}$ & 1 & 2 & 3 & 4 & 5 \\
\hline $\begin{array}{l}\text { 4. Kekuatan tangan kanan anda } \\
\text { 5. Tahap kesakitan tangan kanan } \\
\text { anda }\end{array}$ & 1 & 2 & 3 & 4 & 5 \\
\hline $\begin{array}{l}\text { 6. Deria (rasa) pada tangan kanan } \\
\text { anda }\end{array}$ & 1 & 2 & 3 & 4 & 5 \\
\hline
\end{tabular}

B. Soalan berikut merujuk tahap kepuasan anda terhadap tangan/pergelangan tangan kiri anda pada minggu lepas.

(Sila bulatkan satu jawapan untuk setiap soalan).

\begin{tabular}{|l|c|c|c|c|c|}
\hline & $\begin{array}{c}\text { Sangat } \\
\text { Berpuas } \\
\text { Hati }\end{array}$ & $\begin{array}{c}\text { Agak } \\
\text { Berpuas } \\
\text { Hati }\end{array}$ & Neutral & $\begin{array}{c}\text { Agak Tidak } \\
\text { Berpuas } \\
\text { Hati }\end{array}$ & $\begin{array}{c}\text { Sangat } \\
\text { Tidak } \\
\text { Berpuas } \\
\text { Hati }\end{array}$ \\
\hline $\begin{array}{l}\text { 1. Fungsi keseluruhan tangan kiri } \\
\text { anda }\end{array}$ & 1 & 2 & 3 & 4 & 5 \\
\hline 2. Pergerakan jari tangan kiri anda & 1 & 2 & 3 & 4 & 5 \\
\hline $\begin{array}{l}\text { 3. Pergerakan pergelangan tangan } \\
\text { kiri anda }\end{array}$ & 1 & 2 & 3 & 4 & 5 \\
\hline $\begin{array}{l}\text { 4. Kekuatan tangan kiri anda } \\
\text { 5. Tahap kesakitan tangan kiri } \\
\text { anda }\end{array}$ & 1 & 2 & 3 & 4 & 5 \\
\hline $\begin{array}{l}\text { 6. Deria (rasa) pada tangan kiri } \\
\text { anda }\end{array}$ & 1 & 2 & 3 & 4 & 5 \\
\hline
\end{tabular}


Sila berikan maklumat berikut tentang diri anda. (Sila bulatkan 1 jawapan untuk setiap soalan).

1. Adakah anda pengguna tangan kanan atau tangan kiri (kidal)?
a. Tangan kanan
b. Tangan kiri
c. Kedua-duanya

2. Tangan manakah yang memberikan anda paling banyak masalah?
a. Tangan kanan
b. Tangan kiri
c. Kedua-duanya

3. Pernahkah anda bertukar kerja sejak mengalami masalah dengan tangan anda?
a. $\mathrm{Ya}$
b. Tidak

Sila terangkan jenis pekerjaan yang anda lakukan sebelum mengalami masalah dengan tangan anda

Sila terangkan jenis pekerjaan yang anda lakukan pada masa
ini_

4. Apakah jantina dan umur anda?
a. Lelaki
Umur: tahun
b. Perempuan

5. Apakah latar belakang etnik anda?
a. Melayu
b. Cina
c. India
d. Lain-lain 
6. Apakah tahap pendidikan tertinggi yang anda terima?
a. Sehingga sekolah menengah
b. Diploma
c. ljazah
d. Pascaijazah

7. Berapakah anggaran pendapatan keluarga anda, termasuk gaji, bayaran hilang upaya, pendapatan persaraan dan bantuan kebajikan setiap bulan?
a. $<$ RM 3000
b. RM 3000 - RM6000
c. RM6001 - RM 10000
d. > RM 10000

8. Adakah kecederaan anda dilindungi oleh Pampasan Pekerja (PERKESO)?
a. $\mathrm{Ya}$
b. Tidak

${ }^{1}$ Kevin C. Chung, MD, et al. Reliability and Validity Testing of the Michigan Hand Outcomes Questionnaire. J Hand Surg Am. 1998;23(4):575-87. 